Historia Slavorum Occidentis

2019, nr 3 (22)

ISSN 2084-1213

DOI: $10.15804 /$ hso190302

JoAnna Sobiesiak (Lublin)

\title{
Przemyślidzi między Henrykiem II a Bolesławem Chrobrym, czyli o okolicznościach, które zapoczątkowały zależność lenną czeskich książąt od władców Rzeszy
}

Słowa kluczowe: Bolesław III, książę czeski, Władywoj, Henryk II, Bolesław Chrobry, lenno, Przemyślidzi

Keywords: Boleslaus III, Duke of Bohemia, Vladivoj, Henry II, Bolesław the Brave, oath of fealty, the Přemyslids

\begin{abstract}
The goal of this article is to indicate the political circumstances which led to the Czech king's assumption of the Prague throne as an oath of fealty to the ruler of the Reich. The article discusses the political situation in the late $10^{\text {th }}$ and the early $11^{\text {th }}$ centuries: the weakness of Bohemia following the death of Boleslaus II, the power of Bolesław the Brave and the circumstances accompanying his occupation of Prague together with king Henry II's interference in Czech affairs.
\end{abstract}

Na przełomie X i XI w. pozycja Czech w regionie zdecydowanie osłabła. Powody takiej sytuacji były różnorakie. Przede wszystkim państwo Przemyślidów utraciło na północy na rzecz rosnącej w siłę Polski tereny, z ważnym ośrodkiem handlowym Krakowem. Możliwość ekspansji, a co za tym idzie, bogacenia się państwa została również zahamowana w innych kierunkach. Czeskiej ekspansji w okolice Dunaju stały na przeszkodzie posiadłości Babenbergów, kierunek południowo-wschodni 
zaś, został zablokowany przez coraz silniejsze Węgry Arpadów. Państwo Przemyślidów nie było więc $\mathrm{w}$ stanie wystarczająco zaopatrzyć materialnie rozlokowanych w grodach drużyny ${ }^{1}$. Co więcej, w pierwszych latach XI w. doszło do precedensu politycznego w stosunkach między Czechami i Rzeszą. Chodzi tu o uznanie władztwa czeskiego za obszar zależny od Rzeszy, co w praktyce przekładało się na to, że król niemiecki nadawał Czechy w lenno temu czy innemu kandydatowi, czasami wypełniając wolę wiecu Czechów, a niejednokrotnie wedle własnego uznania. W artykule, mającym charakter syntetyczny, chcę pokazać, że to doniosłe wydarzenie, które przez 200 lat silnie determinowało politykę praskich władców, zapoczątkowane zostało niejako przez przypadek i konieczność polityczną. Słabość czeskich książąt w początku XI w. i starcie dwóch potężnych przeciwników Henryka II z Bolesławem Chrobrym, w efekcie pchnęly Czechy w uzależnienie polityczne od Rzeszy.

Zawirowanie wokół obsady praskiego tronu po śmierci Bolesława II (+999) doprowadziły do zmiany charakteru stosunków politycznych przemyślidzkiego państwa z potężnym sąsiadem Rzeszą Liudolfingów. Niestabilność rządów, na którą złożyło się krótkie panowanie syna Bolesława II, Bolesława III z przydomkiem Rudy (+1037?), władcy - jak osądza go historiografia średniowieczna i współczesna - nie dość, że nieudolnego, to jeszcze okrutnego, doprowadziła do sytuacji, w której w obsadzenie praskiego tronu mogli ingerować obcy władcy ${ }^{2}$. W pierwszym dziesięcioleciu XI w. byli to książę Polski Bolesław Chrobry i król niemiecki Henryk II ${ }^{3}$. Okres ten bywa przez czeskich historyków określany mianem „krize českého státu” ". Ten znaczący czas formowania się relacji z Niemcami na nowych zasadach przypada na okres między

1 J. Žemlička, Expanze, krize a obova Čech v letech 935-1055. (K systémovým proměnám raných státù ve střední Evropě), Český časopis historický 93 (1995), s. 205-221, tu s. 213.

2 Piszący ponad 100 lat później kronikarz Kosmas tak charakteryzuje Bolesława Rudego: Po jego śmierci, [Bolesława II] jak wyżej opowiedziano nastapił w księstwie jego syn Bolestaw III, lecz ani takich samych powodzeń, ani ojcowskim szczęściem zdobytych granic nie zachowat. Zob. Cosmae Pragensis Chronica Boemorum, ed. B. Bretholz, MGH Scriptores rerum Germanicarum, Nova series, t. II, Berlin 1923 (dalej Cosmas), I 34, s. 60; Thietmari Merseburgensis episcopi Chronicon, ed. M. Jedlicki, Poznań 1953, (dalej Thietmar), V 11, s. 265; J. Sláma, Český kniže Boleslav II. [w:] Přemyslovský stát kolem roku 1000. Na pamět' knížete Boleslava II. (+ 7 února 999) red. L. Polanský, J. Sláma, D. Třeštík. Praha 2000, s. 9-26 tu s. 13-14; P. Charvát, Boleslav II. Sjednotitel českého státu, Vyšehrad 2004, s. 178-179.

3 J. Strzelczyk, Bolestaw Chrobry, Poznań 1999, s. 103-160; S. Weinfurter, Heinrich II (1002-1024). Herrscher am Ende der Zeiten, Regensburg 1999, s. 212-214.

4 B. Krzemieńska, Krize českého státu na přelomu tisíciletí, Československý časopis historický 18 (1970), s. 497-532. 
rokiem 999 - objęcie władzy przez Bolesława III - rokiem 1012, kiedy to samodzielne rządy w Pradze przejął najmłodszy syn Bolesława II, Udalryk ${ }^{5}$.

Nic nam nie wiadomo, aby po śmierci ojca, Bolesław III Rudy, przejmując władze w Czechach otrzymał od Ottona III jej potwierdzenie. Czechy, jak się wydaje, znajdowały się na dalekim marginesie cesarskich planów ${ }^{6}$. Wiemy, że wśród krajów słowiańskich, to Polska Bolesława Chrobrego miała odgrywać najznaczniejszą rolę w planach cesarza zmierzających do Renovatio Imperii Romanorum ${ }^{7}$. Czechy można by nawet uznać za stronę pokrzywdzoną w kontekście cesarskich planów. Postanowienia zjazdu gnieźnieńskiego odnośnie powstającej w Polsce organizacji kościelnej uznawały i legalizowały, jako przynależne do władztwa Piastów, ziemie, które Czechy utraciły w latach dziewięćdziesiątych X w. (po osłabieniu pozycji państwa na skutek angażowania się Bolesława II w bunty Henryka Kłótnika) ${ }^{8}$. Zwraca się uwagę, że w roku 1000 zarówno Polska jak i Węgry otrzymały własne metropolie, Praga natomiast nie, mimo że długoletnia (i dłuższa od obu wymienionych krajów) obecność chrześcijaństwa w państwie Przemyślidów mogła w pewien sposób predestynować do tego zaszczytu również Pragę9.

W oparciu o informacje z przekazów źródłowych, czasami niestety dość odległych czasowo od interesujących nas wydarzeń, jak Kronika Kosmasa, wydaje się, że wkrótce po rozpoczęciu rządów, Bolesław III wdał się w konflikty ze wszystkimi ważnymi osobami w państwie ${ }^{10}$. Biskupem Thiedagiem, którego wypędził z diecezji,

5 B. Krzemieńska, Politický vzestup českého státu za knížete Oldřicha (1012-1034), Československý časopis historický 25 (1977), s. 246-270.

6 M. Bláhová, J. Frolík, N Profantová, Velké dějiny zemi Koruny České. I, Praha 1999, s. 345.

7 G. Althoff, Otto III, Darmstadt 1996, s. 126-148; J. Strzelczyk, Otton III, Ossolineum 2000, s. 98-110, 136-137; M. Matla-Kozłowska, Pierwsi Przemyślidzi i ich państwo (od X do połowy XI wieku), Poznań 2008, s. 355-381.

8 R. Michałowski, Zjazd gnieźnieński. Religijne przesłaniki powstania arcybiskupstwa gnieźnieńskiego, Wrocław 2005, s. 73-173; Ch. Warnke, Ursachen und Voraussetzungen der Schenkung Polens an den Heiligen Petrus. [w:] Europa Slavica-Europa Orientalis. Festschrift für Herbert Ludat zum 70. Geburtstag, red. K. Grothusen, K. Zernack, Berlin 1980, s. 127-177; O buntach Henryka Kłótnika i udziału w nich czeskiego księcia zob.: J. Sobiesiak, Bolesław II Przemyślida. Pobożny buntownik i mąż znamienitej damy (+999), Kraków 2017, s. 39-80.

9 Johannes Fried twierdzi natomiast, że w Pradze, zgodnie z planami Ottona III miało powstać arcybiskupstwo św. Wojciecha. Por. J. Fried, Otto III. und Boleslaw Chrobry - das Widmungsbild des Aachener Ewangeliars, der "Akt von Gnesen” und das frühe polnische und ungarische Königtum, Stuttgart 2001, s. 92-105, 122-124. O tym koncepcie zob. też: H. Wolfram, Politická mapa střední Evropy v první polovině 11. století, [w:] Svatý Prokop. Čechy a střední Evropa, red. P Sommer, Praha 2006, s. 15-25, tu s. 20-21.

10 Kosmas przedstawia czytelnikowi właściwie modelowy portret władcy, który nie ma „szczęś- 
możnymi, a nawet z własną rodziną. Jak wiemy, próbował fizycznie wyeliminować przyrodnich braci od ewentualnego pretendowania do tronu. Jaromira kazał wykastrować, a Udalryka na rozkaz księcia usiłowano udusić w łaźni - informuje Thietmar $^{11}$. W końcu wypędził ich razem z matką z kraju. Znaleźli oni schronienie na dworze Henryka III - bawarskiego, który za dwa lata miał zostać królem Rzeszy ${ }^{12}$. Tym samym Bolesław III stracił tradycyjnego sojusznika Czech, jakim dotąd była dla Przmyślidów Bawaria. Czeska badaczka B. Krzemieńska twierdziła, że Bolesław III chcąc zastąpić utraconego sojusznika, zwrócił się w stronę potężnego Ekkeharda, którego pozycja w Rzeszy za rządów Ottona III była potężna ${ }^{13}$. Thietmar, opowiadając o śmierci tego margrabiego i wyliczając jego chwalebne czyny, mówi: Boemiorum ducem Bolizlavum, qui cognominantur Rufus, ad militem sibi aliumque ad amicum familiarem blandiciis ac minis adipiscitur ${ }^{14}$. Wzmianka ta bywa interpretowana różnie. Dla części badaczy dowodzi, że Ekkehard, przez ów akt rozciągał kontrolę nad całymi Czechami, a sam niejako reprezentował w nim cesarza Ottona III ${ }^{15}$. Zdaniem innych, szczególnie czeskich badaczy, zobowiązanie Bolesława III wobec Ekkeharda było akcją osobistą, wynikającą z chęci wzmocnienia słabej we własnym państwie pozycji

cia”, bunt, zdrada, pojmanie przez Bolesława Chrobrego, wszystko to ma przekonać czytelnika, że rządy Bolesława III Rudego były złe. Kronikarza, dużo bardziej interesuje Jaromir, którego uważa za syna Bolesława III. Zob. Cosmas I 34, s. 60-61.

11 Thietmar V 23, s. 283: Interim Boemiorum dux Bolizlaus, quia potestas consortis et successoris est semper pavida, Iaremirum fratrem eunuchizans iunioremque Otelricum in termis suffocere cupiens, una cum matre eosdem patria expulit...

12 S. Weinfurter, Heinrich II, s. 212.

13 B. Krzemieńska, Krize, s. 501.

14 Thietmar V7, s. 257.

15 A. Köster, Die staatlichen Beziehungen der böhmischen Herzöge und Könige zu den deutschen Kaisern von Otto dem Grossen bis Ottokar II., Breslau 1912, s. 6; V. Novotný, České dèjiny, Od nejstarších dob do smrti kníže Oldřicha, I/1, Praha 1912, s. 668; W. Wegener, Böhmen - Mähren und das Reich im Hochmittelalter, Köln - Graz 1959, s. 64; R. Schölkopf, Die sächsischen Grafen (919-1024), Göttingen 1957, s. 66; H. Hoffmann, Böhmen und das deutsche Reich im hohen Mittelalter, [w:] Jahrbuch für die Geschichte Mittel-und Ostdeutschlands 18 (1969), s. 1-62, tu s. 29-30; D. Borawska, Margrabia Miśni Ekkehard i Ludolfingowie, Kwartalnik Historyczny 86 (1979), s. 933-949; G. Rupp, Die Ekkehardiner, Markgrafen von Maißen, und ihre Beziehungen zum Reich und zu den Piasten, Frankfurt am Main 1996, s. 63; A. Pleszczyński, Niemcy wobec pierwszej monarchii Piastowskiej (963-1034). Narodziny stereotypu, Lublin 2008, s. 97, 118-120; D. Kalhous, Boleslav III.: kníže na konci časů, [w:] Ad vitam et honorem. Profesoru Jaroslavu Mezníkovi přátelé a žaci k pětašedesátým narozeninám, red. T. Borovský, L. Jan, M. Wihoda. Brno 2003, s. 221-229, tu s. 223. 
Przemyślidy ${ }^{16}$. Możliwe, że Bolesław sam szukał okazji do nawiązania kontaktów politycznych z Ekkehardem, starając się znaleźć wpływowego sojusznika w sytuacji, gdy jego przyrodni bracia Jaromir i Udalryk znaleźli schronienie na dworze potężnego księcia bawarskiego Henryka III. Z drugiej strony umiejscowienie przez Thietmara tej wiadomości nie pozwala zdecydowanie przesądzić, kiedy ów akt miałby mieć miejsce. Może należałoby go wiązać z czasem, kiedy sam Ekkehard wystąpił z pretensjami do tronu Rzeszy. Jak wiemy, tak ulokowana polityczna lojalność nie na wiele się Bolesławowi Rudemu przydała, ponieważ 30 IV 1002 r. Ekkehard został zamordowany ${ }^{17}$. W końcu Bolesława III przeszedł na stronę Henryka, ale stało się to dopiero po zabójstwie Ekkeharda, co wynika z kroniki Thietmara ${ }^{18}$. Opowiedzenie się po stronie zwycięzcy wydaje się zręcznym i koniunkturalnym posunięciem Przmyslidy. Jednak niedużo to zmieniło w ówczesnym układzie politycznym, bowiem, jak się wydaje dla Henryka, był on w danej chwili osobą mało znaczącą. Nawet jako wasal Ekkeharda, nie był dla Henryka II niebezpieczny. Nic nie wiemy, aby Henryk próbował przeciągnąć Bolesława Rudego na swoją stronę, obiecując jakieś korzyści czy zaszczyty, tak jak to czynił z innymi władcami z regionu. Część badaczy sądzi, że nowemu niemieckiemu królowi wystarczało, że miał w ręku obu jego braci ${ }^{19}$. Tym bardziej, że Bolesław Rudy, o czym zapewne powszechnie wiedziano, musiał być znienawidzony we własnym kraju, ponieważ, jak wynika z przekazu Thietmara, krótko po objęciu władzy przez Henryka II (czescy badacze twierdzą, że stało się to po kwietniu 1002 r.) Bolesław został przez własnych możnych przepędzony. Jest to pierwszy taki przypadek w ponad stuletniej historii Przemyślidzkiego państwa, kiedy książę z panującej dynastii, który przecież objął władzę legalnie, został odsunięty od tronu. Thietmar mówi, że gnębił on lud w sposób trudny do opisania ${ }^{20}$. Choć oczywiście uznajemy wiadomości merseburskiego kronikarza, nie sposób nie być choć odrobinę podejrzliwym i nie szukać inspiratorów buntu przeciw Bolesławowi Rudemu poza Czechami. Nasze podejrzenia- z racji na wypadki, które za chwilę miały nastąpić - paść mogą na Bolesława Chrobrego. Thietmar w tym samym akapicie,

16 B. Krzemieńska, Břetislav I. Čechy a střední Evropa v prvé polovinĕ XI. století, Praha 1999, s. 20-21.

17 H. Patze, Ekkehard Mgf. v. Maißen, Lexikon des Mittelalters. t. 3. J. B. Metzler 2000, k. $1764-1765$.

18 Thietmar V 11, s. $265-266$.

19 B. Krzemieńska, Krize, s. 504.

20 Thietmar V 23, s. 283: (...) solusque vice basilisci noxii regnans populum ineffabiliter constrinxit. 
w którym opowiada o wypędzeniu Bolesława Rudego, informuje, że Czesi z uwagi na pokrewieństwo wybrali sobie jednomyślnie na księcia wezwanego potajemnie z Polski Władywoja ${ }^{21}$. Wygnany Bolesław błąkał się po okolicznych dworach - co znamienne, nie próbował jednak skarżyć się przed obliczem Henryka II - szukając schronienia. Nie znalazł go u Henryka ze Schweinfurtu (margrabiego marchii Nordgau), przeciwnika Henryka II, gdzie został pojmany i uwięziony ${ }^{22}$. Po wypuszczeniu z niewoli Przemyślida znalazł schronienie na dworze Bolesława Chrobrego. Wybór ten, zdaniem Thietmara, podyktowany był łączącym obu Bolesławów pokrewieństwem $^{23}$. Z innych przekazów wiemy, że dynastów tych łączyła „fałszywa przyjaźń i podstępne przymierze", jak rzecz charakteryzuje Adalbold z Utrechtu autor biografii monarszej Henryka II ${ }^{24}$. Jednak również Bolesław Chrobry nie zdecydował się podjąć akcji, która przywróciłaby Bolesława III na praski tron.

Rządy Władywoja choć bardzo krótkie (od kwietnia 1002 r. do początku 1003 r.) 25 zasadniczo zmieniły relacje łączące niemieckich władców z czeskimi książętami. Od panowania Władywoja datuje się początek zwyczajowej zależności lennej czeskich książąt od władcy Rzeszy, a król niemiecki otrzymał prawo potwierdzania księcia elekta, na praskim tronie ${ }^{26}$.

Bez wątpienia pozycja Władywoja w Pradze była słaba. Trudno powiedzieć, w jakim stopniu Władywoj był spokrewniony z Przemyślidami. Zapewne takie związki istniały, trudno bowiem sobie wyobrazić, aby czescy możni, mimo poparcia kandydata przez Bolesława Chrobrego (w połowie Przemyślidę), dozwolili na objęcie

21 Thietmar V 23, s. 283: Qui pondus illati facinoris diucius ferre non valens, Wlodoweium, [...], a Polonia clam vocans, aspidem venenatam absque omni legis pietate suos tractantem, hunc in sedem basilisci illius idest Bolizlai, deiecto eo, consanguinitatis linea et pietatis affect unanimiter electrum, collocavit; J. Strzelczyk, Bolesław, s. 107.

22 Thietmar V 23, s. 284; D. Kalhous, Boleslav III., s. 225-226.

23 Thietmar V 23, s. 285: Sed Bolizlaus. Que sola via fuge patuit, ad Henricum marchionem, qui proximus ei tunc fuerat, confugiens, propter illatas sibi iniurias ab eo captus est (...).

24 Adalbold von Utrecht, Vita Heinrici II imperatoris, ed. M. Schütz, Bamberg 1999, (Berichte des Historische Vereins 135), s. 135-198, tu s. 192: Inter illos igitur duos Bulizlavos fit amicitia ficta, fit societas subdola. Sepe alter ab altero invitatur, sepe alterius sumptibus iocunde convivantur. Zob. także A, Pleszczyński, „Amicitia” a sprawa polska. Uwagi o stosunku Piastów do Cesarstwa $w$ X i na poczatku XI w. [w: ] Ad fontes. O naturze źródła historycznego, red. S. Rosik, P. Wiszewski, Wrocław 2004, s. 49-58, tu s. 53.

25 Velké dějiny zemi, Př́lohy, s. 740.

26 Z. Fiala, Vztah českého státu k nĕmeckě řiši do počátku 13. století, (Podle kritiky pramenů), Sbornik Historický 6 (1959), s. 23-95, tu s. 59; Velké dějiny zemi, s. 353. 
tronu osobie spoza dynastii. Zresztą Thietmar, którego trudno zaliczyć do osób przychylnych Władywojowi, nazywa go „żmiją jadowitą”, zanotował, że otrzymał on praski tron jednomyślnie z uwagi na pokrewieństwo i wielką sympatię, jak się można domyślać, możnych czeskich ${ }^{27}$. Władywoj, choć zapewne był jakoś politycznie związany z Bolesławem Chrobrym, chcąc umocnić swoje panowanie w Pradze, udał się do Ratyzbony, gdzie uznał zwierzchność Henryka II. Jako pierwszy z czeskich władców poprosił o nadanie mu Czech w lenno, stało się to w listopadzie $1002 \mathrm{r} .^{28}$ Henryk oczywiście spełnił żądanie czeskiego księcia. Bez wątpienia akcja Władywoja była korzystna dla rozpoczynającego panowanie króla, dawała mu też, w zasadzie bez ponoszenia wysiłku, okazję do rozciągnięcia kontroli nad Czechami, a co ważniejsze, stworzony w ten sposób precedens został już w czasach Henryka II uznany za „stare prawo”, które dawało niemieckim królom okazję do ingerowania w wewnętrzne sprawy Czech $^{29}$. Władywoj oczywiście skorzystał z, jak się wydaje, najpewniejszego sposobu zabezpieczenia świeżo nabytego władztwa. Odwołał się do zewnętrznej potęgi, interesując niemieckiego władcę utrzymaniem własnej osoby na książęcym tronie ${ }^{30}$. Dla Władywoja była to więc polityczna konieczność w sytuacji, kiedy dwaj Przemyślidzi Jaromir i Udalryk przebywali w Rzeszy.

Śmierć Władywoja na początku 1003 r. (dokładnej daty nie znamy) była początkiem trwającego kilkanaście miesięcy zamętu politycznego w Czechach. O władzę w Pradze upomnieli się synowie Bolesława II. Thietmar podaje, że to Czesi odwołali $\mathrm{z}$ wygnania braci wraz z matką ${ }^{31}$. Jednak tym razem wtrącił się już zbrojnie Bolesław

27 Thietmar V 23, s. 283: Wlodoweium (...) a Polenia clam vocans, aspidem venenatam absque omni legis pietate suos tractantem, hunc im sedem basilisci illius, idest Bolizlai, deiecto eo, consanguinitatis linea et pietatis affectu unanimiter electum, collocavit.; B. Krzemieńska, Krize, s. 506. 28 Ch. Lübke, Regesten zur Geschichte der Slaven an Elbe und Oder (vom Jahre 900 an). t. III, Berlin 1986, s. 359; W. Wegener, Böhmen - Mähren, s. 65.

29 J. Razim, Vèrní Přemyslovci a barbarští Čechové, Praha 2017, s. 146-151.

30 Velké dějiny zemi, s. 353; K. Görich, Eine Wende im Osten, Heinrich II Und Boleslav Chrobry. [w:] Otto III. - Heinrich II. Eine Wende?, red. B. Schneidmüller, S. Weinfurter, Sigmaringen 1997, s. 95-167, tu s. 107-109; A. Pleszczyński, Przestrzeń i polityka. Studium rezydencji władcy wcześniejszego średniowiecza, Lublin 2000, s. 28; M. Matla-Kozłowska, Pierwsi Przemyślidzi s. 387. Martin Wihoda przypuszcza, że przez ten akt Władywoj pragną uwolnić się spod politycznej kurateli Bolesława Chrobrego, ponieważ Piast był dla Władywoja zbyt potężnym sąsiadem. M. Wihoda, Morava v době knížecí 906-1197, Praha 2010, s. 107.

31 Thietmar V 29, s. 291: Mortuo interea duce Wlodoweio, fratres predicti, una cum matre expulsi, Boemensibus penitencea ductis revocantur. 
Chrobry. Po wtargnięciu do Czech zmusił młodych Przemyślidów do ustąpienia ${ }^{32}$. Zwraca uwagę, że jeszcze w tym okresie niemiecki król zajęty był innymi problemami politycznymi, a sprawa obsadzenia czeskiego tronu nie stanowiła dla niego na tyle istotnej kwestii, by podejmować jakieś militarne działania.

Za sprawą Bolesława Chrobrego władza w Czechach na przełomie stycznia i lutego 1003 r., ponownie znalazła się w ręku Bolesława III. Zapewne jednym z elementów układu politycznego, dzięki któremu Bolesławowi Rudemu udało się powrócić do władzy w Pradze, był obiecany Chrobremu udział w buncie przeciw Henrykowi II ${ }^{33}$. Bolesław Rudy nie miał, jak się wydaje, okazji, by wypełnić przyjęte zobowiązanie, ponieważ ledwo kilka miesięcy po powrocie do Pragi został z niej ponownie wypędzony ${ }^{34}$. Na podstawie późnego przekazu Kosmasa przyjmuje się, że trzon opozycji przeciw księciu stanowił ród Wrszowców ${ }^{35}$. Thietmar ponownie informuje o wysłanych potajemnie do Bolesława Chrobrego posłach, którzy mieli za zadanie nakłonić Piasta do interwencji przeciw Bolesławowi Rudemu. W rozwiązaniu czeskiego problemu ujawnił się cały kunszt polityczny Chrobrego. Zamiast wyruszać na Pragę z wojskiem, kronikarz donosi, że Piast przez zaufanego człowieka zaprosił Bolesława Rudego na spotkanie, a gdy ten przybyl, wyłupiono mu oczy - by, jak komentuje Thietmar - unieszkodliwić go w ten sposób ${ }^{36}$.

Po usunięciu Bolesława III, Chrobry objął rządy w Pradze i sprawował je od marca 1003 r. do września 1004 r. ${ }^{37}$ Przyjmuje się, że najpewniej w 1003 r. opanował również Morawy ${ }^{38}$. Nasz najlepszy informator Thietmar z Merseburga podaje, że

32 J. Strzelczyk, Bolesław, s. 108; A. Pleszczyński, Bolesław Chrobry w Czechach. Realizacja ideii Sklawinii czy zwykła ekspansja?, [w: ] Polacy w Czechach, Czesi w Polsce X-XVIII wiek. red. H. Gmiterek, W. Iwańczak, Lublin 2004, s. 133-146, tu s. 135.

33 Annales Hildesheimenses, MGH SS t. III, ed. G.H. Pertz, Hannover 1987, s. 92: Pod datą roczną 1003 r.: „Heinricus, Berhthaldi comitis filius et Bruno, frater eius, et ambo Bolizlavones, Polianicus videlicet ac Boemicus, a rege infideliter maiestatis rei deficiunt"; B. Krzemieńska, Krize, s. 510.

34 Velké dëjiny zemi, s. 353-354.

35 Cosmas I 37, s. 68; O konflikcie między Bolesławem III zobacz też. J. Žemlička, Rod Přemyslovců na rozhraní 10. a 11. Století, [w:] Přemyslovský stát kolem roku 1000. Na pamèt' knížete Boleslava II. (+ 7 února 999), red. L. Polanský, J. Sláma, D. Třeštík. Praha 2000, s. 267-273, tu s. 272; M. Matla-Kozłowska, Pierwsi Przemyślidzi, s. 388.

36 Thietmar, V 29, s. 293.

37 Velké dějiny zemi, Př́lohy, s. 740

38 B. Krzemieńska, Krize, s. 507 n; Velké dějiny zemi,s. 534; M. Wihoda, Morava, s. 107, 110. 
mieszkańcy Pragi wprowadzili Chrobrego i obwołali jednomyślnie swoim władcą ${ }^{39}$. W odmiennym tonie o panowaniu Chrobrego w Pradze wypowiadała się późniejsza czeska tradycja. Kosmas, który zresztą konsekwentnie nazywa Bolesława Chrobrego Mieszkiem, zdobycie przez niego władzy przypisuje wielkiej armii, za pomocą której Piast miał opanować Pragę.

Charakter władzy Bolesława Chrobrego w Czechach budzi rozliczne kontrowersje. Czeska mediewistyka ocenia rządy Chrobrego w Pradze jako uzurpację. Nie ma pewności, czy został formalnie praskim księciem, to znaczy, czy odbył ceremoniał intronizacyjny w Pradze ${ }^{40}$, choć część polskich historyków utrzymuje, że tak właśnie było $^{41}$. Z przywołanej wyżej relacji Thietmara wynika, że zajęcie Pragi odbyło się w sposób pokojowy i nie spowodowało naruszenia politycznej stabilności władzy. Niektórzy tłumaczą fakt zwrócenia się możnych czeskich po śmierci Bolesława III do Chrobrego w kontekście, jakoby to Chrobry, po śmierci Ekkeharda w 1002 r. przejął jego „zwierzchność” nad Czechami ${ }^{42}$. Prostszym wytłumaczeniem byłoby raczej wskazanie na fakt, że Bolesław Chrobry był przez matkę w połowie Przemyślidą, zatem przynależność to tego rodu mogła ułatwić mu objęcie praskiego tronu. Osobną i nie mniej trudną do wyjaśnienia sprawą pozostaje, dlaczego czescy możni zwrócili się do Bolesława Chrobrego, a nie do jednego z synów Bolesława II Przemyślidy. Wypada w tym miejscu dać wiarę przekazowi Kosmasa, który mocno wyeksponował konflikt między młodymi książętami, a na pewno Jaromirem, a czeskimi możnymi, gdzie główną rolę miał odgrywać znienawidzony przez kronikarza ród Wrszowców ${ }^{43}$ - przeciwko którym podjął represje Bolesław III - co miało stać się bezpośrednim powodem jego usunięcia. Zatem to możni czescy dysponowali wedle swojego uznania praskim tronem.

39 Thietmar, V 30, s. 293: (Bolizlaus) In sequenti igitur die ad Pragam velociter properans, ab incolis semper de nova dominacione gaudentibus introducitur communiterque in domnum laudatur.

40 B. Krzemieńska, Krize, s. 511; M. Bláhová, Středověké katalogy českých knížat a králů a jejich pramenná hodnota, [w: S Średniowiecze polskie i powszechne. red. I. Panic, t. I, Katowice 1999, s. 49-50. Zob. Też M. Matla-Kozłowska, Pierwsi Przemyślidzi, s. 391. O ceremoniale intronizacyjnym w Czechach zob.: M. Kulecki, Ceremoniat intronizacyjny Przemyślidów w X-XIII wieku, Kwartalnik Historyczny 75 (1984), s. 441-451.

41 J. Strzelczyk, Bolestaw Chrobry, s. 109.

42 A. Pleszczyński, Bolesław Chrobry, s. 133 - 138.

43 Cosmas I 34, s. 61-62; Velké dējiny zemi, s. 354. 
Początkowo Henryk II zapewne zajęty planowaną wyprawą do Włoch, uznał politykę Chrobrego w Czechach, licząc przypuszczalnie na możliwość wykorzystania potężnego polskiego księcia we własnych planach politycznych. Na żądanie Piasta, poparte dużą sumą pieniędzy - o czym informuje Kosmas - Henryk zgodził się uwięzić Udalryka. Zgorszony, jeszcze po 100 latach - Kosmas podaje, że niemiecki król skuszony rządzą złota, przystał na tę propozycje ${ }^{44}$. Do zerwania porozumienia doszło dopiero, kiedy Piast nie zgodził się uznać, że jego władza nad Czechami ma charakter lennego nadania z rąk Henryka II ${ }^{45}$. Oczywiście powodem odmowy przez Chrobrego uznania czeskiej zdobyczy za lenno otrzymane od niemieckiego króla, mogło być zwykłe poczucie siły i urażona duma po próbie zamachu na jego życie podczas zjazdu w Merseburgu w sierpniu 1002 r. W większości starszej literatury fakt ten był interpretowany jako szczególne okazanie niemieckiemu władcy lekceważenia przez Piasta, ponieważ odmówił uznania zwierzchności Henryka wobec ziem czeskich, które były - choćby w sprawach Kościoła - częścią niemieckiego systemu politycznego. Powoływano się tu na uwagę Thietmara, który opisując stosunek Czech względem niemieckiego państwa, dość niejasno mówił o „starym prawie" - ius antiquum - według niego Czechy należało traktować jako niemieckie lenno ${ }^{46}$. Knut Görich słusznie zauważył, że choć władcy czescy niemalże od początku istnienia państwa byli politycznie związani z niemieckimi królami, to charakter tych związków nie jest do końca jasny. Zwrócił zasadnie uwagę, że pierwszym potwierdzonym źródłowo faktem nadania przez niemieckiego króla Czech w lenno, jest zaistniała ledwie ponad rok wcześniej w stosunku do omawianych wypadków okoliczność związana z objęciem praskiego tronu przez Władywoja ${ }^{47}$. Piszący kilka lat po zaistniałych wypadkach Thietmar, nadanie Czech w lenno, chciał i mógf postrzegać istotnie jako trwałą praktykę, bo zarówno Jaromir jak i Udalryk w ten sposób potwierdzili swoją władzę.

\footnotetext{
44 Cosmas I 35, s. 63; Z. Fiala, Vztah, s. 60.

45 Thietmar V 31, s. 293: Hec omnia rex dicante fama comperiens [...] nuncios ad Bolizlaum misit, mandans ei, si terram nuper a se occupatam de sua gracia, ut ius antiquum poscit, retinere sibique in omnibus fideliter vellet servire, se eius voluntati in hiis assentire, sin alias, se armis illi velle contraire. Hanc legacionem, etsi iustam et bene compositam, tamen Bolizlaus indigne suscipiens; J. Strzelczyk, Bolesław Chrobry, Poznań 1999, s. 112.; B. Krzemieńska, Krize, s. 513.

46 A. Köster, Die staatlichen Beziehungen, s. 8; W. Wegener, Böhmen - Mähren, s. 93. Więcej na ten temat zob.: Ch. Lübke, Regesten, t. III, s. 365 .

47 K. Görich, Eine Wende, s. 108; H. Hoffmann, Böhmen, s. 30-31.
} 
Trudno przewidzieć, w jakim stopniu odmowa uznania Czech za niemieckie lenno przez Chrobrego, a w jakim przyłączenie się Bolesława do opozycji w Niemczech ostatecznie skłoniło Henryka II do interwencji w Czechach. Bez wątpienia Chrobry stał się dla niemieckiego króla niebezpieczny. Przypomnijmy, że udzielił pomocy zbuntowanemu Henrykowi ze Schweinfurtu i podjął próbę dywersji w Miśni, po czym dał schronienie buntownikom wśród nich wspomnianemu margrabiemu Henrykowi i królewskiemu bratu Brunonowi ${ }^{48}$. Nieudana wyprawa Henryka II na Milsko w lutym 1004 r. zapewne wzmocniła pozycję Chrobrego w układzie si1 ${ }^{49}$.

Po powrocie z Italii król, w sierpniu 1004 r., zgromadził w Merseburgu potężną $\operatorname{armię}^{50}$. Do ostatniej chwili utrzymywano w tajemnicy cel wojny, by jak mówi Thietmar, ochronić zamiary króla przed szpiegami Bolesława Chrobrego ${ }^{51}$. Ostatecznie Henryk wyruszył przeciw Bolesławowi Chrobremu kierując się na Czechy. W armii Henryka zmierzającej do Czech znajdował się też Jaromir Przemyślida ${ }^{52}$. Zdaje się, że wojsko Henryka bez większych przeszkód wkroczyło na teren Kotliny Czeskiej. Obecność Jaromira ułatwiła Henrykowi tuż po wejściu do Czech zdobycie jakiegoś grodu. Obecnie czescy badacze przyjmują, że był to Chlumec ${ }^{53}$, w polskiej literaturze obecny był pogląd, że chodzi o Gniewin (dziś Brüx nad Białą) ${ }^{54}$. W czeskiej historiografii spotykamy się z opinią, że Czesi nie stawiali oporu armii Henryka, ponieważ prowadziła ona Przemyslidę do Pragi. Twierdzi się, że od grodu Żatec armii Henryka towarzyszyły pośpiesznie zebrane czeskie oddziały ${ }^{55}$. Następnie Jaromir wyruszył na Pragę, do walki jednak nie doszło, ponieważ ostrzeżeni w ostatniej chwili Polacy (dzwonami z Wyszehradu) uciekli w popłochu ${ }^{56}$. Zwraca uwagę, że

\footnotetext{
48 J. Strzelczyk, Bolesław, s. 115-117; Ch. Lübke, Regesten. III s. 372.

49 Ch. Lübke, Regesten, III, 377.

50 J.F. Böhmer, Regesta Imperii II. Sächsisches Haus 919-1024; vol. 4. Die Regesten des Kai-
} serreiches unter Heinrich II. 1002-1024. ed. T. Graff, Wien 1971, 1580a.

51 Thietmar VI 10, s. 328; J. Strzelczyk, Bolestaw, s. 118.

52 Thietmar VI 11, s. 329: Adiuvit eciam regem exulis Iaremiri, qui firma pax interpretatur, comitatus, et adoptatus eiusdem adventus Boemiorum delinivit agmen.; B. Krzemieńska, Krize, s. 517; Ch. Lübke, Regesten, III, 387.

53 B. Krzemieńska, Krize, s. 518.

54 J. Strzelczyk, Bolesław, s. 119.

55 Velké dějiny zemi, s. 355; B. Krzemieńska, Krize, s. 517-518; M. Matla-Kozłowska, Pierwsi Przemyślidzi, s. 397-398.

56 Thietmar VI 12, s. 331: Hic legatione tali commonitus clam se preparavit et, subsequenti nocte iam mediante, audiens in urbe proxima, quae Wissegrodi dicitur campanas cives ad 
Chrobry nie próbował stawiać oporu czeskim i niemieckim oddziałom idącym na Pragę. Przejawiająca się tu słabość pozycji Chrobrego w Czechach częściowo mogła wynikać z zaskoczenia, ale całkiem możliwe, że była konsekwencją utraty poparcia tych, którzy nie tak dawno wynieśli go na praski tron ${ }^{57}$. Po wkroczeniu do Pragi Jaromir został uznany władcą i intronizowany. Przybywszy do Pragi Henryk II obdarzył Jaromira wszystkimi godnościami, jakie posiadał jego ojciec - podaje Thiet$\operatorname{mar}^{58}$. Ustęp ten jest interpretowany jako wiadomość o nadaniu Jaromirowi Czech w lenno ${ }^{59}$. W kronice Hermanna z Reichenau (biskupa augsburskiego) znajduje się wiadomość, pod datą 1004 r. o tym, że Henryk zmusił Czechów do płacenia trybu$\mathrm{tu}^{60}$. W czeskiej historiografii przyjmuję się tę wiadomość za mylną, odwołując się do lepiej poinformowanego Thietmara, który nie wspominał o żadnym narzuconym Czechom trybucie ${ }^{61}$. W nowszej historiografii nie wyklucza się jednak takiej możliwości (to znaczy istnienia trybutu z Czech) z uwagi na sytuację polityczną w dobie władzy Jaromira i Udalryka ${ }^{62}$.

Za pomoc w zdobyciu praskiego tronu, Jaromir zapewne został zobowiązany do uczestnictwa przy boku Henryka II w wyprawie przeciw Chrobremu do ziemi Milczan na przełomie września i października 1004 r. Wspierał też przy boku króla zakończone sukcesem oblężenie Budziszyna w $1004 \mathrm{r}^{63}$ Również w roku następnym Jaromir pospieszył przy boku Henryka na wyprawę przeciw Polsce. Tym razem w wojnie po stronie niemieckiego króla wziął udział jeszcze jeden sojusznik: pogańscy Lucice. Henryk II odwrócił się tym samym od dotychczasowej polityki

bellum sonitu hortantes, cum prima legione exivit et patriam fugiendo revisit.; Cosmas, I 36, s. 64.

57 M. Matla-Kozłowska, Pierwsi Przemyślidzi, s. 398, przypis 787.

58 Thietmar VI 12, s. 333: Cunctis mox dignitatibus a rege honoratur Iaremirus paternis convocatis indigenis coram omnibus.

59 Z. Fiala, Vztah, s. 60; B. Krzemieńska, Krize, s. 519; zob. też Ch. Lübke, Regesten, III, 387; Zob. też J. Razim, Vèrní Přemyslovci, s. 151-158.

60 Herimanni Augiensis Chronicon, red. G. H. Pertz. vol. V. MGH SS. Hannover 1987, 118. Pod data roczną 1004: Post paucos dies in Sclavos arma convertit, Boemanisque ad pristinam servititutem tributumque redactis. Bolizlaum etiam, ducem Sclavorum Bolanorum cum tota gente sua subiugavit (...).

61 Por. Z. Fiala, Vztah, s. 51, 54.

62 H. Hoffmann, Böhmen, s. 23-24. Twierdzi on, że był to powrót do „starej zależności” zobowiązującej do płacenia trybutu. Zob. też M. Matla-Kozłowska, Pierwsi Przemyślidzi, s. 398, przypis 788.

63 Thietmar VI 14, s. 335; B. Krzemieńska, Krize, s. 521. 
państwa, w której to Piastowie byli sojusznikami Liudolfingów w walce z pogańskimi plemionami Połabia. Zwracano uwagę, że postąpił zgodnie z tradycją bawarskich dynastów - z których przecież się wywodził, gdzie wiedziano o tradycyjnie dobrych stosunkach Czechów z ludami połabskimi. Badacze zwracają uwagę, że to dzięki pośrednictwu Czechów, czy też ich obecności po stornie niemieckiego króla, udało się przekonać Henrykowi Luciców do wspólnej wojny przeciw Chrobremu ${ }^{64}$. Działania wojenne zakończyły się pokojem, który prawdopodobnie nie zadowolił żadnej ze stron $^{65}$. Już dwa lata później, w roku 1007, Henryk zdecydował się na nową wojnę przeciw Chrobremu. Choć Piast zrezygnował z prób utrzymania się w Czechach, to sprawy czeskie, czyli lojalność polityczna księcia praskiego, musiała być dla polityki Chrobrego istotną sprawą. Dlatego też, zapewne początkowo na drodze negocjacji, próbował rozerwać niewygodny sojusz i przeciągnąć na swoją stronę Jaromira, Luciców i Wolinian. Jak wiadomo, zamiar ten się nie powiódl. Możliwe, że ze strony Chrobrego pojawił się także groźby, co by wyjaśniało wiadomość podaną przez Thietmara, że tym razem to Czesi do spółki z Lucicami nalegali na Henryka, by ten wyruszył na wojnę przeciw Chrobremu ${ }^{66}$. Wyprawa przeciw Chrobremu ruszyła w 1010 r., także ta wojna nie przyniosła Henrykowi spodziewanych rezultatów. W armii Henryka znalazł się również Jaromir, o którym Thietmar mówi przy tej okazji, że był całkowicie królowi oddany ${ }^{67}$. Konsekwentna obecność Jaromira z wojskiem u boku Henryka na kolejnych wyprawach nie dziwi. Jaromir, objąwszy praski tron, dzięki wsparciu Henryka przez całe swoje panowanie (1004-1012) prowadził politykę jak najściślej wiążącą go z interesami niemieckiego króla.

64 J. Strzelczyk, Bolesław, s. 120-121, 123-126; S. Weinfurter, Heinrich II., s. 208; G. Althoff, Die Ottonen. Königsherrschaft ohne Staat, Stuttgart 2000, s. 160-161. Zwraca się też uwagę na fakt, że Henryk użył Jaromira, aby ten przekonał Lucicow do wsparcia królewskiej polityki. Książę czeski musiał się odwołać do „starego sojuszu” łączącego Czechów z tym plemieniem. Zob.: K. Görich, Eine Wende, s. 104-111; D. Třeštík, Ještě ke královnĕ Emmĕ. Wolfenbüttelský rukopis Gumpoldovy Legendy a druhý život královny Matyldy. [w:] Od knížat ke králüm. Sborník u príležitosti 60. narozenin Josefa Žemličky, red. E. Doležalova, R. Šimůnek. Praha 2007, s. 23-37, tu s. 27.

65 Thietmar VI 27, s. 273; K. Görich, Eine Wende, s. 152-160; J. Strzelczyk, Bolesław, s. 127;

G. Althoff, Die Ottonen, s. 163-164. Ch. Lübke, Regesten, III, 400.

66 Thietmar VI 33, s. 361-363; G. Althoff, Die Ottonen, s. 164; B. Krzemieńska, Krize, s. 521; Ch. Lübke, Regesten, III, 407.

67 Thietmar VI 56-58, s. 395: Venit etiam huc Iarimirus, Boemiorum dux inclitus et regi per omnia fidelis, Zob. A. Köster, Die staatlichen Beziehungen, s. 121. 
Straty terytorialne, które dotknęły Czechy w końcu X w. i na początku XI w., oraz naruszenie stabilności wyboru księcia osłabiały w kraju pozycję Jaromira. Mimo objęcia tronu nie znalazł sposobu do wydźwignięcia swojej władzy i państwa z trudnego położenia. Dodatkowo był kastratem i nie mógł mieć potomstwa, co na pewno osłabiało jego pozycję w oczach poddanych i możnych, których potęga w ostatnich latach wyraźnie wzrosła. W tej sytuacji wydawało się, że jedynym gwarantem jego władzy nad Czechami, może być ten, który faktycznie osadził go na praskim tronie, czyli Henryk II ${ }^{68}$. Możliwe, że na wierność Jaromira wobec polityki Henryka wpływał fakt, że w otoczeniu niemieckiego króla przebywał jego młodszy brat i potencjalny konkurent do władzy - Udalryk.

Polityka wierności względem Henryka II, jak się okazało, nie zabezpieczyła władzy Jaromira w Czechach. Na skutek intrygi Udalryka, nic bliższego poza domysłami o kulisach tej akcji nie wiemy, Jaromir został pozbawiony tronu i wypędzony z Czech. Tradycyjnie już za Kosmasem, jako inspiratorów buntu wskazuje się możny ród Wrszowców ${ }^{69}$. Thietmar sytuuje to wydarzenie na sobotę poprzedzającą Wielkanoc 1012 r. Zwraca uwagę, że pozbawiony tronu Przemyślida na dworze Bolesława Chrobrego szukał schronienia, co prawda bezskutecznie ${ }^{70}$. W kontekście wydarzeń $\mathrm{z}$ lat poprzednich musi zastanawiać wybór takiego kierunku. Ciekawe jest, że Jaromir, nie uzyskawszy pomocy od Chrobrego, mógł swobodnie udać się do Niemiec. Najwidoczniej jego pozycja musiała być do tego stopnia słaba, że Chrobry nie uważał, aby warto go było na wszelki wypadek uwięzić jako kartę przetargową czy to w rozrywkach z królem, czy nowym czeskim księciem ${ }^{71}$.

Dziwić powinno, dlaczego Jaromir od razu nie zwrócił się o pomoc do Henryka II, wszak to z jego ręki otrzymał władzę w Pradze. Dzięki relacji Thietmara dowiadujemy się, że powodem uniemożliwiającym zwrócenie się Jaromira o pomoc do Henryka II była sprawa bawarskiego poselstwa do Bolesława Chrobrego, które przechodząc przez Czechy zostało wycięte na rozkaz Jaromira. Najpewniej motywem działania Jaromira był przekonanie, że robi to w interesie Henryka II, tym bardziej że poselstwo to działało bez wiedzy króla, co wyraźnie stwierdza Thietmar ${ }^{72}$. Jednak

68 J. Žemlička, Společnost v područi státu, [w:] Přemyslovci. Budováni českého státu, red. P. Sommer, D. Třeštík, J. Žemlička, Praha 2009, s. 165.

69 Velké dějiny zemi, s. 357.

70 Thietmar VI 71, s. 413; V. Novotný, České dějiny, s. 698-701.

71 B. Krzemieńska, Krize, s. 524

72 Thietmar VI 83, s. 427-429; J. Strzelczyk, Bolestaw, s. 135. 
Henryk II odwrócił się od swojego niedawnego wiernego sojusznika wykorzystując, jak się wydaje, jako pretekst właśnie sprawę owego bawarskiego poselstwa. Słusznie sądzi się, że wobec zatargów z Polską i konfliktów z opozycją wewnątrz Rzeszy Henryk II nie miał sił ani chęci do angażowania się w przywracanie Jaromira do władzy, uznał więc władzę Udalryka w Czechach, tym bardziej, że nowy książę deklarował się jako stronnik niemieckiego króla. Pozbawiony jakiegokolwiek wsparcia Jaromir starał się zyskać łaskę Henryka przez protekcję arcybiskupa magdeburskiego Walterda. Niestety przedwczesna śmierć dostojnika pokrzyżowała te plany, a Jaromir został zesłany do Utrechtu ${ }^{73}$.

W tym samym roku, kilka miesięcy później na zjeździe w Merseburgu w październiku 1012 r., Henryk nadał Czechy w lenno Udalrykowi ${ }^{74}$. Rzecz jest o tyle istotna, że władca Rzeszy zadysponował czeskim lennem w sytuacji, kiedy jego decyzja miała jedynie znaczenie formalne, ponieważ Pragą już władał Udalryk ${ }^{75}$. Powtórzyła się więc sytuacja, która miała miejsce już za panowania Władywoja. W obu przypadkach żądanie nadania Czech w lenno, z jakim zwrócili się do króla ci książęta, należy rozpatrywać jako próbę zabezpieczenia świeżo nabytego tronu przed pretensjami odsuniętych od władzy i wypędzonych z kraju członków dynastii. Z punktu widzenia Henryka istotne było, aby nadal mieć w czeskim księciu sojusznika w walkach przeciw Chrobremu.

Udalryk (1012-1033) dobrze potrafił wykorzystać fakt, że Henryk II uwikłany był w konflikt z Bolesławem Chrobrym. Pokój pomiędzy Piastem a Liudolfingiem zawarty 23 V 1013 r. w Merseburgu przyniósł tylko chwilowe zastopowanie konfliktu $^{76}$. Przemyślida zapewne zdawał sobie sprawę, że tak jak jego poprzednik, może być cennym sojusznikiem dla władcy Rzeszy. Zwraca uwagę, że pomimo otrzymania Czech w lenno z rąk Henryka II nie wziął udziału w „rzymskiej jeździe” króla, czyli wyprawie po koronę cesarką w 1014 r. Jak wiemy, od końca XI w. uczestnictwo w takiej wyprawie zaczęło być postrzegane jako obowiązek praskich władców ${ }^{77}$. Udział

73 B. Krzemieńska, Krize, s. 524, przyp. 107; M. Matla-Kozłowska, Pierwsi Przemyślidzi, s. 407-409.

74 Thietmar VI 83, s. 427-429: Post haec Othelricus frater eius ad Merseburg a rege vocatus venit et regnum, quod sibi iniuste prius usurpavit, gratuito munere suscepit.

75 Z. Fiala, Vztah, s. 61; B. Krzemieńska, Krize, s. 526; E. Mikušek, Ideové pojetí vztahu českého státu k ř́iši německé v dílech dějepisců 10. a 11. Století, Sborník Historicky 26 (1979), s. 5-59, tu s. 15-16; Velké dĕjiny zemi, s. 357.

76 Ch. Lübke, Regesten, III 463-465.

77 J. Volf, Účast českých panovniků při řišských výpravách, Časopis Musea královstvi českého 
w wyprawie przyrzekł natomiast podczas pobytu w Merseburgu Bolesław Chrobry, który jednak obietnicy nie dotrzyma17 ${ }^{78}$.

Podczas bytności Henryka w Italii Bolesław Chrobry starał się uczynić z Przemyślidy swojego sojusznika przeciw cesarzowi. Thietmar donosi, że Bolesław powołując się na pokrewieństwo wysłał do Udalryka syna Mieszka z darami, aby pozyskać jego pomoc przeciw cesarzowi ${ }^{79}$. Jednak Przemyślida pojmał Mieszka i go uwięził. Część badaczy sugeruje, że Udalryk zapoznał się najpierw z propozycjami przedstawionymi przez polskie poselstwo, a dopiero gdy oferta okazała się mało satysfakcjonująca (na przykład brak zgody na oddanie Przemyślidom Moraw), postanowił zatrzymać młodego Piastowicza. Jak wiemy, o Mieszka upominał się zarówno Bolesław jak i Henryk, nakazując uwolnienie go jako swojego lennika, z rąk Udalryka ${ }^{80}$.

Przekazy z epoki odnotowały obecność księcia czeskiego na zjeździe wielkanocnym 1015 r. w Merseburgu. Nieobecność Bolesława Chrobrego mimo cesarskiego wezwania była sygnałem tego, że zbliża się nowa wojna ${ }^{81}$. W obu wyprawach Henryka II przeciw Bolesławowi Chrobremu z 1015 i 1017 r. Czesi wymieniani są jako sojusznicy cesarza. Co prawda w wojnie 1015 r. oddziały czeskie ostatecznie nie wzięły udziału $^{82}$. Thietmar lakonicznie donosi, że książę czeski zrezygnował z połączenia się z wojskami cesarza z różnorodnych przyczyn ${ }^{83}$. Decyzję tę być może podjął na wieść o zatrzymaniu Bawarów przez dywersję Chrobrego, a może na wiadomość o wycofaniu się wojsk saskich Przemyślida nie podjął ryzykownej wyprawy i ograniczył się do spustoszenia jakiegoś terenu na Łużycach ${ }^{84}$. Nie lepiej dla Czechów przebiegała kampania wojenna 1017 r. Podczas pobytu Udalryka z wojskiem przy boku cesarza Polacy urządzali najazdy na Czechy. Mieszko wtargnął z 10 oddziałami

82 (1908), ss. 171-184; J. Sobiesiak, Od Lechowego Pola (955) do Mediolanu (1158). W stużbie monarchów Rzeszy. Relacje czeskich źródeł narracyjnych o wyprawach Przemyślidów, Lublin 2011, s. 57-89.

78 Thietmar VI 92, s. 447; J. Strzelczyk, Bolesław, s. 138-139.

79 Thietmar VII 10-12, s. 483-485.

80 J. Strzelczyk, Bolestaw Chrobry, s. 140; G. Althoff, Die Ottonen, s. 170; G. Labuda, Mieszko II. 1025-1034, Poznań 1994, s. 64-66.

81 Ch. Lübke, Regesten, IV, 488.

82 A. Köster, Die staatlichen Beziehungen, s. 122.

83 Thietmar VII 19, s. 497: „Othelricus quoque, qui cum Bawariis ad cesarem venire debuit, ob multas causarum qualitates dimisit." 
do Czech i przez dwa dni plądrował kraj, po czym wycofał się z wielkim tłumem jeńców $^{85}$. Akcja ta miała zapewne na celu odciągnięcie Udalryka od głównych sił Henryka. Cel ten nie został osiągnięty, ponieważ Czesi wraz z armią cesarską i Lucicami pomaszerowali na Śląsk. Jednak armii Henryka nie udało się zdobyć tamtejszych grodów, wobec epidemii dziesiątkujących armię, król wycofał się przez Czechy jak komentuje Thietmar ${ }^{86}$. Prawdopodobnie to wtedy (choć są i inne propozycje datacji tego wypadu) Chrobry wysłał do Czech oddział 600 piechurów, którzy mieli dokonać złupienia kraju, lecz wpadli w czeską zasadzkę. Jak widać, niebezpiecznie dla Udalryka działania wojenne zaczęły rozgrywać się również na terenie jego kraju. Wyczerpanie wojną obu stron, jak również chęć bądź konieczność angażowania się politycznego $w$ innych kierunkach doprowadziły w efekcie do zawarcia pokoju w Budziszynie w $1018 \mathrm{r} .{ }^{87}$ Bez wątpienia stroną, która na tym pokoju zyskała więcej, był Bolesław Chrobry ${ }^{88}$. Jednak pośrednio również Udalryk skorzystał na zakończeniu wojen z Henryka II z Piastem. Już w roku 1018 Bolesław, wspomagany przez wojska Henryka, wyruszył na Ruśs9. Przeniesienie ciężaru politycznego zainteresowania Chrobrego na wschód pozwoliło Czechom odzyskać Morawy. Data tego wydarzenia pozostaje sporna. Najczęściej kładzie się je na rok $1019^{90}$.

W przeciągu najbliższych pięciu lat dwaj główni polityczni gracze: Henryk II i Bolesław Chrobry zmarli. Umocniony na tronie Udalryk nie potrzebował dłużej wsparcia ze strony nowego niemieckiego władcy, dlatego też nie zareagował, kiedy Konrad II, uważający się za jego seniora, wezwał go na wyprawę przeciw Polsce ${ }^{91}$.

85 Thietmar VII 59-60, 63, s. 553-555, 559; J. Strzelczyk, Bolestaw Chrobry, s. 154; M. Matla - Kozłowska, Pierwsi Przemyślidzi, s. 416-418.

86 Thietmar VII 63, s. 559; J. Strzelczyk, Bolesław Chrobry, s. 155.

87 Ch. Lübke, Regesten, IV, 534.

88 J. Strzelczyk, Bolestaw, s. 158-159; S. Weinfurter, Heinrich II., s. 211, 219.

89 J. Strzelczyk, Bolestaw, s. 169-185.

90 Kosmas datuje zdobycie Moraw na okres przed 1021 r. Por. Cosmas I 40, s. 75; W. Wegener, Böhmen - Mähren, s. 115; B. Krzemieńska, Politický, s. 249; Velké dějiny zemi, s. 360-361; J. Žemlička twierdzi, że do zajęcie tego obszaru mogło dojść w roku 1019 (1020). Historyk ten stwierdza, że Czesi mogli utracić najpierw tylko Morawy północne. Por. J. Žemlička, Čechy $v$ době knížecí (1034-1198), Praha 1997, s. 27, 42-44. Na ten temat zobacz także: M. Wihoda, Morava, s. 109-110; H. Łowmiański, Początki Polski, VI/1, Warszawa 1985, s. 35-57; G. Labuda, Mieszko II, s. 85-89; M. Matla-Kozłowska, Pierwsi Przemyślidzi, s. 400-405; 434-451. Zob. też M. Lysý, Politika českého kniežat'a Břetislava I. (1035-1055) voči Uhorsku, Historický Časopis 52/3 (2004), s. 451-468, tu s. 452-455.

91 Z. Fiala, Vztah, s. 62; B. Krzemieńska, Politický, s. 251; M. Matla-Kozłowska, Pierwsi Pr- 
Zdaniem V. Novotnego Udalryk obecny był podczas wyboru Konrada II na króla w Kambie 4 IX 1024 r. i krótko potem przyjął od niego Czechy w lenno ${ }^{92}$. Twierdzenie to zapewne opiera się na fragmencie kroniki Wipona, gdzie autor wyliczając dostojników kościelnych i książąt Rzeszy obecnych na dworze, kiedy Henryk zmarł, wśród wielu innych wymienia także Udalryka, księcia $\mathrm{Czech}^{93}$. Nigdzie nie można wskazać źródłowej informacji, która uprawniałaby do stwierdzenia, że Udalryk złożył Konradowi II hołd lenny z Czech. B. Krzemieńska stwierdziła, że o ewentualnej podległości Udalryka wobec nowego niemieckiego króla nie wiemy nic ${ }^{94}$. Ustalenia te pozwalają zakładać, że podległość lenna władców czeskich wobec niemieckiego króla czy cesarza, nie była w pierwszej ćwierci XI w. utrwaloną instytucją.

Rok 1012, w którym doszło do objęcia władzy przez Udalryka bywa postrzegany jako granica oznaczająca początek końca okresu określanego mianem kryzysu państwa czeskiego. Badacze zwracają uwagę, że nie tylko straty terytorialne, ale przede wszystkim kryzys struktury władzy osłabił czeskie państwo w pierwszych latach XI w. Wszyscy poprzednicy Udalryka z XI w. obejmowali władzę w oparciu o potęgę Bolesława Chrobrego lub Henryka II. Dopiero Udalryk był tym, który tę praktykę przełamał, choć przecież i tak wsparł swoje rządy uznaniem formalnego zwierzchnictwa niemieckiego króla. Barbara Krzemieńska zwróciła uwagę na fakt wydawałoby się - oczywisty, którego wymowa jednak chyba dość mocno wspierała pozycję Udalryka w stosunku do jego poprzedników od końca X w. Otóż on jeden spośród nich miał syna, co odsuwało groźbę wymarcia dynastii ${ }^{95}$. Niemniej jednak zaistniały w 1002 r. precedens polityczny, jakim było odwołanie się do niemieckiego króla - podkreślam: króla, a nie cesarza - w celu ugruntowania władzy nad Czechami, stał się wygodnym narzędziem politycznym w rozgrywkach o praski tron do końca XII w. Korzystali z niego nie tylko władcy Rzeszy, ale również przedstawiciele dynastii Przemyślidów, którzy starali się zneutralizować swoich braci i kuzynów, konkurentów do władzy nad Czechami. Sposobem na to było odwołanie się, często wsparte dużą sumą pieniędzy, do prawa nadawania w lenno tronu czeskiego, którym rzekomo dysponował król niemiecki.

zemyślidzi, s. 423-424. Ch. Lübke, Regesten. IV, 589; F. Prinz, Böhmen im mittealterlichen Europa, München 1984, s. 88.

92 V. Novotný, České dějiny, s. 718, przyp. 1.

93 Wipon, Gesta Chuonradi II Imperatoris, ed. J. Sochacki, Kraków 2005, I, s. 85.

94 B. Krzemieńska, Politický, s. 251; Velké dějiny zemi, s. 378. Opinię taką wyrażają nawet niemieccy badacze: zob: W. Wegener, Böhmen - Mähren, s. 67; A. Köster, Die staatlichen, s. 10. 95

B. Krzemieńska, Politický, s. 248. 
Nadesłany: 17 V 2019

Nadesłany po poprawkach recenzyjnych: 31 VIII 2019

Zaakceptowany: 29 IX 2019

Dr hab. Joanna Sobiesiak

Katedra Historii Starożytnej i Średniowiecznej

Uniwersytet Marii Curie Skłodowskiej

pl. M. Curie-Skłodowskiej 4a

20-031 Lublin

joanna.sobiesiak@poczta.umcs.lublin.pl

\section{The House of Přemyslid between Henry II and Boleslaus the Brave or the circumstances which commenced an oath of fealty taken by Czech dukes to the rulers of the Reich}

The article summarises in a synthetic form the political circumstances which resulted in a habit where a Czech ruler assumed the Bohemian throne as fealty held by the ruler of the Reich. Between the early $11^{\text {th }}$ and the late $12^{\text {th }}$ centuries, it was standard behaviour for the Přemyslid dukes to confirm their rule over Bohemia via the German king. However, not all Prremyslids addressed the ruler of the Reich to complete the act. This article discusses the political situation in the late $10^{\text {th }}$ and the $11^{\text {th }}$ centuries with special emphasis placed on Czech issues. The key task here was to present the political situation in Bohemia following Boleslaus II's death. In Bohemia it was a time of a power crisis and therefore weakening the position of Czech rulers against their powerful neighbours: Bolesław the Brave and king Henry II. The turmoil accompanying the assumption of the throne in Prague and the political games played by Bolesław the Brave and Henry II led to an oath of fealty sworn by Vladivoy, duke of Bohemia, to Henry in 1002. This act, stemming from impromptu political circumstances, became a precedence referred to in the subsequent years not only by rulers of the Reich but also Czech dukes who intended to secure the throne from their relatives' designs. 